\title{
Peranan Jenis Media, Sumber Hormon Alami dan Teknik Induksi Akar Planlet dalam Aklimatisasi Pule Pandak
}

\author{
Siti Rochmah ${ }^{凶}$ 1), Enni Suwarsi Rahayu ${ }^{2)}$ \\ 1),2) Jurusan Biologi, Fakultas Matematika dan Ilmu Pengetahuan Alam Universitas Negeri Semarang, Indonesia
}

\section{Info Artikel}

Diterima: 1 September 2021

Disetujui: 30 September 2021

Dipublikasikan: 30

November 2021

\section{Keywords:} natural hormones;media;root induction techniques hormon alami;media;teknik induksi akar

\begin{abstract}
Pule pandak is a plant that has medicinal. Pule pandak seeds have a hard coat that makes it difficult to germinate naturally. Plant tissue culture can be an alternative that is able to overcome the difficulty of seed germination which then needs to be acclimatized. Factors that influence the success of acclimatization include media type, induction technique and growth regulators. This study aims to analyze the role of media types, natural hormone sources and plantlet root induction techniques. This study used a randomized block design with three factors, the type of media (cocopeat, vermiculite and sand), natural hormone sources (coconut water and bean sprouts extract) and root induction techniques (in vitro + ex vitro and ex vitro). The parameters observed were the number of roots, number of leaves, plant height and percentage of life. Data were analyzed by three-way Anava and Duncan's Multiple Range Test. The results showed that the type of media had no effect on the number of roots, number of leaves, plant height and percentage of life. Natural hormone sources of bean sprouts extract affect the number of roots, number of leaves and plant height. Root induction techniques in vitro + ex vitro affected number of roots.
\end{abstract}

\begin{abstract}
Abstrak
Pule pandak adalah tanaman yang memiliki khasiat sebagai bahan obat. Biji pule pandak memiliki kulit biji yang keras sehingga sulit berkecambah secara alami. Kultur jaringan tanaman dapat menjadi salah satu alternatif yang mampu mengatasi kesulitan perkecambahan biji yang selanjutnya perlu dilakukan aklimatisasi. Faktor-faktor yang mempengaruhi keberhasilan aklimatisasi antara lain jenis media, teknik induksi dan zat pengatur tumbuh. Penelitian ini bertujuan untuk menganalisis peranan jenis media, sumber hormon alami dan teknik induksi akar planlet. Penelitian ini menggunakan rancangan acak kelompok tiga faktor yaitu jenis media (cocopeat, vermikulit dan pasir), sumber hormon alami (air kelapa dan ekstrak tauge) dan teknik induksi akar (in vitro+ex vitro dan ex vitro). Parameter yang diamati adalah jumlah akar, jumlah daun, tinggi tanaman dan persentase hidup. Data dianalisis dengan Anava tiga arah dan Duncan's Multiple Range Test. Hasil penelitian menunjukkan bahwa jenis media tidak berpengaruh terhadap jumlah akar, jumlah daun, tinggi tanaman dan persentase hidup. Sumber hormon alami ekstrak tauge berpengaruh terhadap jumlah akar, jumlah daun dan tinggi tanaman. Teknik induksi akar secara in vitro +ex vitro berpengaruh terhadap jumlah akar.
\end{abstract}

(C) 2021 Universitas Negeri Semarang 


\section{PENDAHULUAN}

Pule pandak adalah tanaman yang memiliki khasiat sebagai bahan obat. Rendahnya populasi pule pandak di Indonesia karena sulit dikembangbiakkan secara alamiah. Biji pule pandak memiliki kulit biji yang keras sehingga sulit berkecambah, pule pandak termasuk tanaman yang hampir punah dan status tanaman ini berada pada Apendiks II CITES (Convention International Trade of Endangered Species) (Widaryanto \& Azizah, 2018). Kultur jaringan tanaman dapat menjadi salah satu alternatif penerapan teknologi yang mampu mengatasi kesulitan perkecambahan biji. Melalui metode ini diharapkan dapat dihasilkan bibit pule pandak dalam jumlah yang besar. Pembibitan tanaman pule pandak menggunakan teknik kultur jaringan tanaman sudah berhasil dilakukan menggunakan media MS (Murashige \& Skoog) yang ditambah ZPT (Zat Pengatur Tumbuh) yaitu NAA (Naphtaleine Acetic Acid) $0,2 \mathrm{mg} / 1$ dan kinetin 1-1,5 mg/1. Hasil yang diperoleh adalah terbentuknya tunas yang tumbuh menjadi planlet yang perlu dilakukan aklimatisasi (Mukherjee et al. 2020).

Aklimatisasi adalah tahapan adaptasi planlet dari kondisi in vitro ke kondisi lingkungan ex vitro (Priyadi \& Hendriyani, 2016). Pada tahap aklimatisasi planlet mengalami periode kritis. Planlet yang tumbuh dalam kondisi in vitro memiliki stomata lebih terbuka, jumlah stomata tiap satuan luas lebih banyak dan atau tidak memiliki lapisan kutikula pada permukaannya (Mariska \& Sukmadjaja, 2003). Faktor-faktor yang mempengaruhi keberhasilan aklimatisasi antara lain jenis media, teknik pengakaran dan zat pengatur tumbuh (Slamet, 2011).

Media aklimatisasi harus tidak menjadi sumber penyakit bagi tanaman, memiliki aerasi dan drainase yang cukup baik serta dapat memegang air dengan baik. Contoh media aklimatisasi adalah sekam bakar, cocopeat, serbuk pakis dan moss (Sandra, 2013). Media cocopeat adalah limbah hasil industri yang berpotensi sebagai media (Prasetyawan, 2009). Media ini memiliki daya serap air yang baik, $\mathrm{pH}$ netral dan mengandung unsur hara secara alami yang dapat menunjang pembibitan (Artha, 2014). Media vermikulit adalah media anorganik yang dihasilkan dari pemanasan kepingan-kepingan mika yang mengandung potasium dan helium. Sifat vermikulit adalah memiliki kapasitas tukar kation yang baik (Maligan, 2014). Media pasir adalah media yang memiliki tekstur dan aerasi yang baik serta dapat menopang tegaknya tanaman (Kusumawati et al. 2015).

Pemanfaatan teknik aklimatisasi ex vitro sudah diterapkan pada penelitian yang dilakukan Purmadewi et al. (2019) pada planlet tembesu (Fagraea fragrans). Planlet yang diaklimatisasi memiliki persentase berakar yang rendah dan akar tidak memanjang. Masalah tersebut mungkin dapat dilakukan dengan penambahan hormon eksogen untuk meningkatkan akar. Hormon dapat diberikan dalam bentuk sintetik atau alami. Penggunaan hormon sintetik dapat dilakukan, salah satu hormon sintetik yang dapat ditambahkan adalah IBA (Khan et al. 2018) tetapi harganya yang mahal masih menjadi kendala sehingga perlu adanya alternatif penggunaan hormon alami. Hormon alami memiliki beberapa keunggulan yaitu murah, mudah didapat dan memiliki kandungan senyawa yang beragam. Hormon alami yang dapat digunakan adalah air kelapa dan ekstrak tauge. Air kelapa mengandung hormon auksin dan sitokinin. Komposisi kimia dalam air kelapa adalah kinetin 273,62 mg/1 dan zeatin 290,47 
mg/1, sedangkan kandungan IAA adalah 198,55 mg/1 (Kristina \& Syahid, 2012). Tauge adalah jenis sayuran yang umum dikonsumsi. Ekstrak tauge memiliki konsentrasi hormon auksin 1,68 ppm, giberelin 39,94 ppm dan sitokinin 96,26 ppm (Ulfa, 2014). Penelitian ini bertujuan untuk menganalisis peranan jenis media, sumber hormon alami, teknik induksi akar terhadap pertumbuhan dan persentase hidup pule pandak.

\section{METODE}

Penelitian ini dilakukan di Rumah Teduh Laboratorium Biologi Fakultas Matematika dan Ilmu Pengetahuan Alam Universitas Negeri Semarang. Penelitian dilaksanakan selama 2 bulan. Populasi pada penelitian ini adalah planlet pule pandak yang terdapat di Laboratorium Kultur Jaringan Tumbuhan Jurusan Biologi Universitas Negeri Semarang. Sampel yang digunakan adalah planlet pule pandak yang memiliki kriteria jumlah daun 5 buah dan tinggi minimal $3 \mathrm{~cm}$. Instrumen utama penelitian ini adalah penggaris dengan ketelitian $0,1 \mathrm{~cm}$. penelitian ini menggunakan rancangan acak lengkap (RAL) dengan 3 faktor. Faktor pertama adalah jenis media yang terdiri atas cocopeat, vermikulit dan pasir. Faktor kedua adalah sumber hormon alami yang terdiri dari air kelapa dan ekstrak tauge. Pada penelitian ini menggunakan hormon IBA $1 \mu \mathrm{M}$ sebagai pembanding. Faktor ketiga adalah teknik induksi akar yang terdiri atas teknik induksi akar secara in vitro dan teknik induksi akar secara ex vitro. Pada penelitian ini terdapat 18 perlakuan yang diulang sebanyak 3 kali ulangan. Unit penelitian adalah 1 gelas plastik berisi 1 planlet. Planlet ditempatkan di Rumah Teduh dengan suhu berkisar $27^{\circ} \mathrm{C}$, intensitas cahaya 634 lux dan kelembaban $52 \%$.

Parameter yang diamati adalah jumlah akar, jumlah daun, tinggi tanaman dan persentase hidup planlet. Data dianalisis menggunakan Anava tiga arah dengan taraf perlakuan $p \leq 0,05$. Hasil uji yang signifikan dilakukan uji lanjut DMRT (Duncan's Multiple Range Test) dengan tingkat kepercayaan 95\% untuk menganalisis perbedaan pengaruh antar taraf perlakuan dan kombinasinya.

\section{HASIL DAN PEMBAHASAN}

\section{Jumlah Akar}

Hasil penelitian jenis media, sumber hormon alami dan teknik induksi akar pada 4 MST dapat dilihat pada Tabel 1 dan Gambar 1. Data menunjukkan rerata jumlah akar planlet pule pandak bervariasi antar perlakuan.

Tabel 1. Respon jumlah akar terhadap jenis media, sumber hormon alami dan teknik induksi akar planlet pule pandak

\begin{tabular}{lccccccccc}
\hline & \multicolumn{1}{c}{ Jumlah akar } \\
\cline { 2 - 10 } Perlakuan & \multicolumn{4}{c}{ Cocopeat } & \multicolumn{4}{c}{ Vermikulit } & \multicolumn{3}{c}{ Pasir } \\
\cline { 2 - 10 } & IBA & $\begin{array}{c}\text { Air } \\
\text { kelapa }\end{array}$ & $\begin{array}{c}\text { Ekstrak } \\
\text { tauge }\end{array}$ & IBA & $\begin{array}{c}\text { Air } \\
\text { kelapa }\end{array}$ & $\begin{array}{c}\text { Ekstrak } \\
\text { tauge }\end{array}$ & IBA & $\begin{array}{c}\text { Air } \\
\text { kelapa }\end{array}$ & $\begin{array}{c}\text { Ekstrak } \\
\text { tauge }\end{array}$ \\
\hline In vitro+ex vitro & 6,00 & 1,33 & 7,66 & 2,33 & 0,33 & 3,33 & 5,66 & 1,33 & 7,00 \\
Ex vitro & 4,33 & 1,00 & 1,00 & 7,00 & 0,66 & 0,66 & 3,66 & 1,33 & 1,00 \\
\hline
\end{tabular}




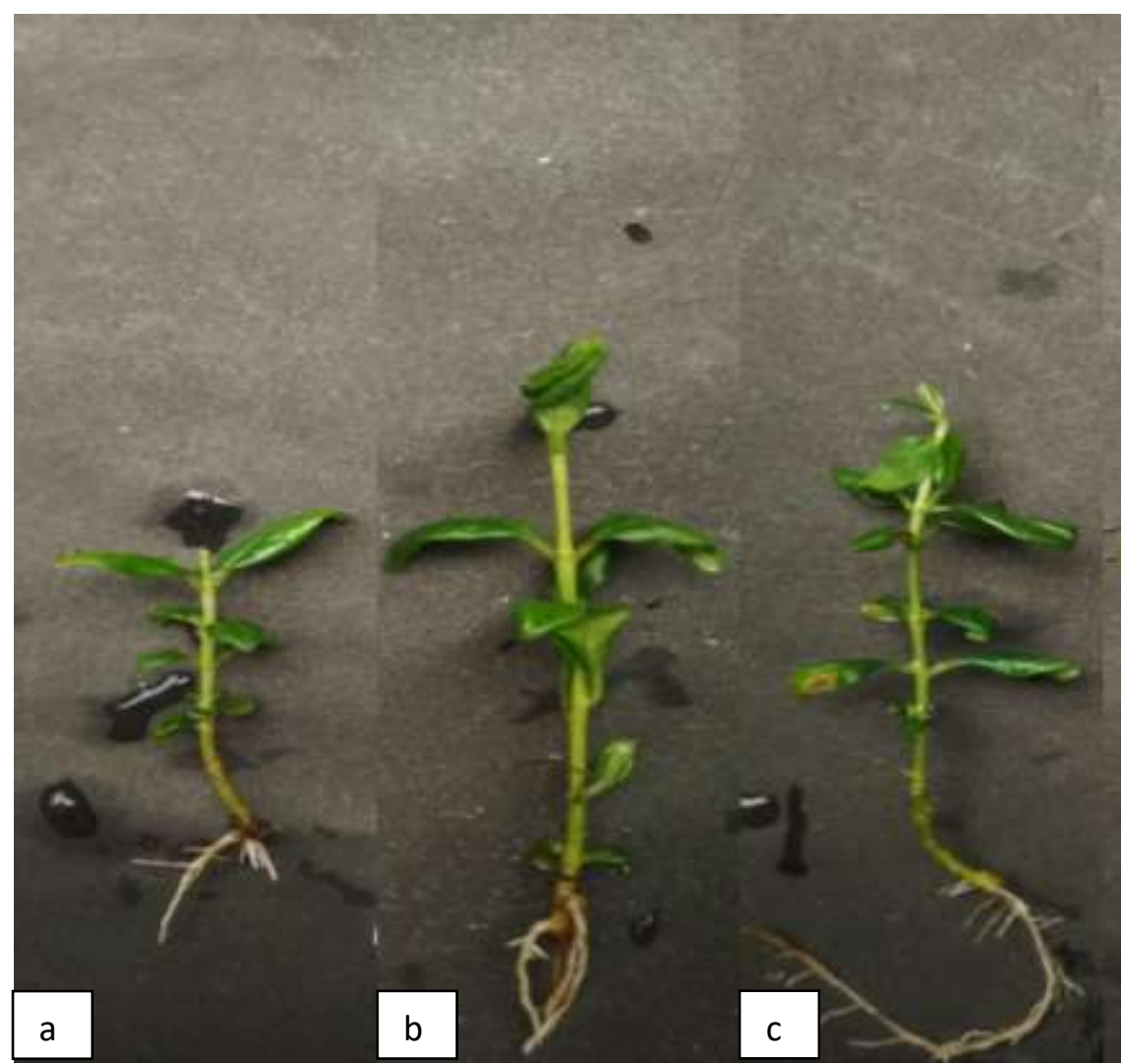

Gambar 1 Jumlah akar (a) cocopeat * air kelapa * induksi akar ex vitro (b) vermikulit * ekstrak tauge * induksi akar in vitro + ex vitro (c) pasir * IBA * induksi akar in vitro + ex vitro. Scale bar: $2 \mathrm{~cm}$

Hasil analisis Anava tiga arah menunjukkan bahwa respon jumlah akar planlet pule pandak dipengaruhi signifikan oleh hormon dan teknik induksi akar. Hasil uji lanjut sumber hormon alami menunjukkan bahwa ekstrak tauge memiliki pengaruh yang setara dengan IBA (Tabel 2). Teknik induksi akar secara in vitro lebih berpengaruh terhadap jumlah akar.

Tabel 2. Hasil uji Duncan pada hormon terhadap jumlah akar planlet pule pandak

\begin{tabular}{cc}
\hline Hormon & Jumlah akar \\
\hline IBA $1 \mu \mathrm{M}$ & $6,05^{\mathrm{a}}$ \\
Air kelapa & $2,22^{\mathrm{b}}$ \\
Ekstrak tauge & $4,66^{\mathrm{a}}$ \\
\hline
\end{tabular}

Ekstrak tauge dapat dijadikan alternatif pengganti hormon IBA untuk meningkatkan jumlah akar. Hal ini sejalan dengan penelitian bahwa penambahan ekstrak tauge sebanyak $20 \mathrm{~g} / \mathrm{L}$ menunjukkan hasil terbaik pada parameter jumlah akar kentang (Fadhillah, 2015). Ekstrak tauge memiliki kandungan auksin berupa IAA 3,74\% dan IBA 1,88\% (Sunandar et al. 2017). Auksin berperan pada pertumbuhan dan perkembangan tanaman. Peran fisiologis auksin diantaranya yaitu mendorong perpanjangan sel, pembelahan sel, dominansi apikal, diferensiasi jaringan xylem floem dan merangsang pembentukan akar (Arif et al. 2016). Hormon yang terdapat dalam air kelapa belum optimal untuk 
meningkatkan jumlah akar planlet pule pandak diduga karena konsentrasi auksin di dalam air kelapa yang tinggi sehingga kadar auksin dalam planlet pule pandak justru menghambat pembentukan akar. Tinggi rendahnya konsentrasi auksin endogen dalam tanaman juga mempengaruhi jumlah akar. Rasio auksin lebih tinggi daripada sitokinin cenderung mengarah pada pembentukan akar. Kadar hormon yang lebih tinggi dapat menghambat pertumbuhan bahkan meracuni tanaman (George \& Klerk, 2007).

Akar yang di induksi secara in vitro memiliki hasil jumlah akar yang lebih banyak dibandingkan dengan akar yang di induksi secara ex vitro. Hal ini dikarenakan akar in vitro telah dihasilkan terlebih dahulu pada media yang mengandung nutrisi dan dalam kondisi lingkungan yang disesuaikan untuk pengakaran, sedangkan akar ex vitro dilakukan bersamaan dengan tahap aklimatisasi yang ketersediaan nutrisi dalam media rendah (Purmadewi et al. 2019).

\section{Jumlah Daun}

Hasil penelitian jenis media, sumber hormon alami dan teknik induksi akar pada 4 MST dapat dilihat pada Tabel 3 dan Gambar 2. Data menunjukkan rerata jumlah daun planlet pule pandak bervariasi antar perlakuan.

Tabel 3. Respon jumlah daun terhadap jenis media, sumber hormon alami dan teknik induksi akar planlet pule pandak

\begin{tabular}{|c|c|c|c|c|c|c|c|c|c|}
\hline \multirow{3}{*}{ Perlakuan } & \multicolumn{9}{|c|}{ Jumlah daun } \\
\hline & \multicolumn{3}{|c|}{ Cocopeat } & \multicolumn{3}{|c|}{ Vermikulit } & \multicolumn{3}{|c|}{ Pasir } \\
\hline & IBA & $\begin{array}{c}\text { Air } \\
\text { kelapa }\end{array}$ & $\begin{array}{c}\text { Ekstrak } \\
\text { tauge }\end{array}$ & IBA & $\begin{array}{c}\text { Air } \\
\text { kelapa }\end{array}$ & $\begin{array}{c}\text { Ekstrak } \\
\text { tauge }\end{array}$ & IBA & $\begin{array}{c}\text { Air } \\
\text { kelapa }\end{array}$ & $\begin{array}{c}\text { Ekstrak } \\
\text { tauge }\end{array}$ \\
\hline In vitro + ex vitro & 4,33 & 2,00 & 3,00 & 5,00 & 3,33 & 5,00 & 4,66 & 3,00 & 3,33 \\
\hline Ex vitro & 2,33 & 3,00 & 3,33 & 6,00 & 3,66 & 8,00 & 8,33 & 1,00 & 7,33 \\
\hline
\end{tabular}

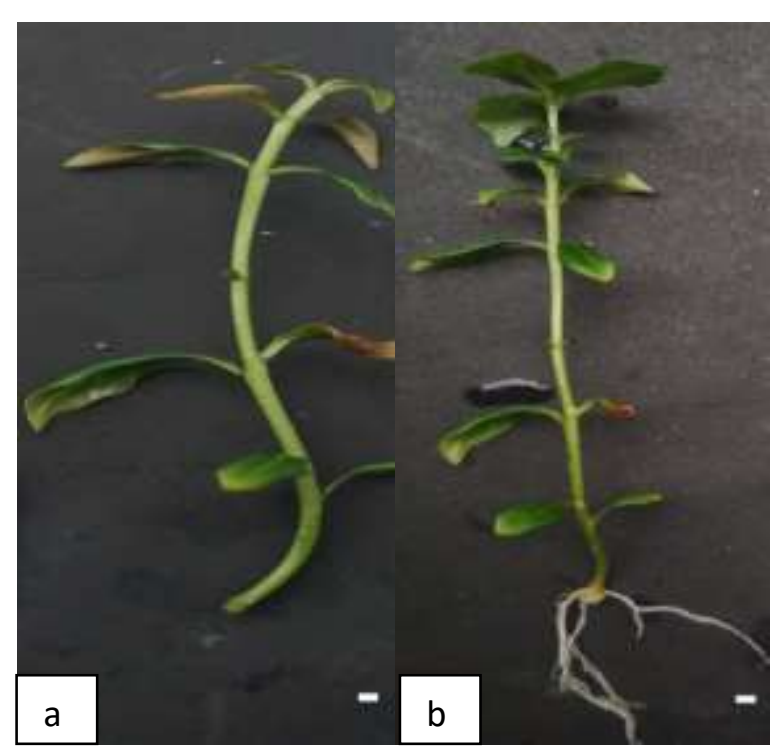

Gambar 2. (a) jumlah daun awal 12 helai (b) jumlah akhir daun 18 helai. Scale bar: $2 \mathrm{~cm}$ 
Hasil analisis Anava tiga arah menunjukkan bahwa respon jumlah daun planlet pule pandak dipengaruhi signifikan oleh sumber hormon alami. Hasil uji lanjut sumber hormon alami menunjukkan bahwa ekstrak tauge berpengaruh paling signifikan terhadap jumlah daun (Tabel 4).

Tabel 4. Hasil uji Duncan pada hormon terhadap jumlah daun planlet pule pandak

\begin{tabular}{cc}
\hline Hormon & Jumlah daun \\
\hline IBA & $15.38^{\mathrm{b}}$ \\
Air kelapa & $13.83^{\mathrm{b}}$ \\
Ekstrak tauge & $21,50^{\mathrm{a}}$ \\
\hline
\end{tabular}

Pada hasil analisis Anava tiga arah yang telah dilakukan menunjukkan bahwa hanya perlakuan hormon yang berpengaruh signifikan terhadap jumlah daun. Media, teknik induksi akar, interaksi media dan hormon, interaksi media dan teknik induksi akar, interaksi hormon dan teknik induksi akar, interaksi media, hormon dan teknik induksi akar tidak berpengaruh signifikan terhadap jumlah daun aklimatisasi planlet pule pandak. Hal ini menunjukkan bahwa perlakuan-perlakuan tersebut memberikan efek yang sama terhadap jumlah jumlah daun planlet pule pandak.

Hasil uji lanjut pada perlakuan hormon terhadap jumlah daun menunjukkan hasil yang signifikan adalah ekstrak tauge.Bahkan hasil uji lanjutnya lebih tinggi dibandingkan dengan hormon sintetik yaitu IBA, sehingga ekstra tauge juga dapat dijadikan sebagai alternatif pengganti hormon IBA dalam aklimatisasi. Penggunaan air kelapa menunjukkan hasil yang tidak signifikan diduga karena jumlah hormon dalam air kelapa dan hormon endogen planlet pule pandak yang saling berinteraksi berlebihan kadarnya sehingga menghambat pertumbuhan daun baru.

Hormon yang memiliki pengaruh terhadap pertumbuhan daun adalah auksin dan giberelin. Fungsi auksin yaitu dapat berperan dalam proses pemanjangan sel pada pucuk tanaman sehingga dapat membantu dalam perbanyakan jumlah daun (Artanti, 2007). Giberelin berpengaruh pada pertumbuhan tanaman karena dapat memacu perkembangan daun sehingga laju fotosintesis meningkat (Arif et al. 2016). Hormon auksin dan giberelin yang terkandung di dalam ekstrak tauge di duga berinteraksi dengan hormon endogen planlet pule pandak dengan optimal sehingga dapat meningkatkan pertumbuhan daun baru. Penggunaan ekstrak tauge berpengaruh nyata terhadap jumlah daun tanaman gaharu (Jayanti et al. 2019).

\section{Tinggi Tanaman}

Hasil penelitian jenis media, sumber hormon alami dan teknik induksi akar pada 4 MST dapat dilihat pada Tabel 5 dan Gambar 3. Data menunjukkan rerata tinggi tanaman planlet pule pandak bervariasi antar perlakuan. 
Tabel 5. Respon tinggi tanaman terhadap jenis media, sumber hormon alami dan teknik induksi akar planlet pule pandak

\begin{tabular}{lcccccccccc}
\hline & \multicolumn{1}{c}{ Tinggi tanaman } \\
\cline { 2 - 10 } Perlakuan & \multicolumn{4}{c}{ Cocopeat } & \multicolumn{4}{c}{ Vermikulit } & \multicolumn{3}{c}{ Pasir } \\
\cline { 2 - 10 } & IBA & $\begin{array}{c}\text { Air } \\
\text { kelapa }\end{array}$ & $\begin{array}{c}\text { Ekstrak } \\
\text { tauge }\end{array}$ & IBA & $\begin{array}{c}\text { Air } \\
\text { kelapa }\end{array}$ & $\begin{array}{c}\text { Ekstrak } \\
\text { tauge }\end{array}$ & IBA & $\begin{array}{c}\text { Air } \\
\text { kelapa }\end{array}$ & $\begin{array}{c}\text { Ekstrak } \\
\text { tauge }\end{array}$ \\
\hline In vitro+ex vitro & 2.83 & 0.66 & 1.63 & 1.60 & 0.40 & 1.36 & 1.16 & 0.36 & 0.83 \\
Ex vitro & 0.93 & 0.26 & 1.73 & 2.60 & 0.20 & 1.43 & 0.56 & 0.50 & 2.03 \\
\hline
\end{tabular}

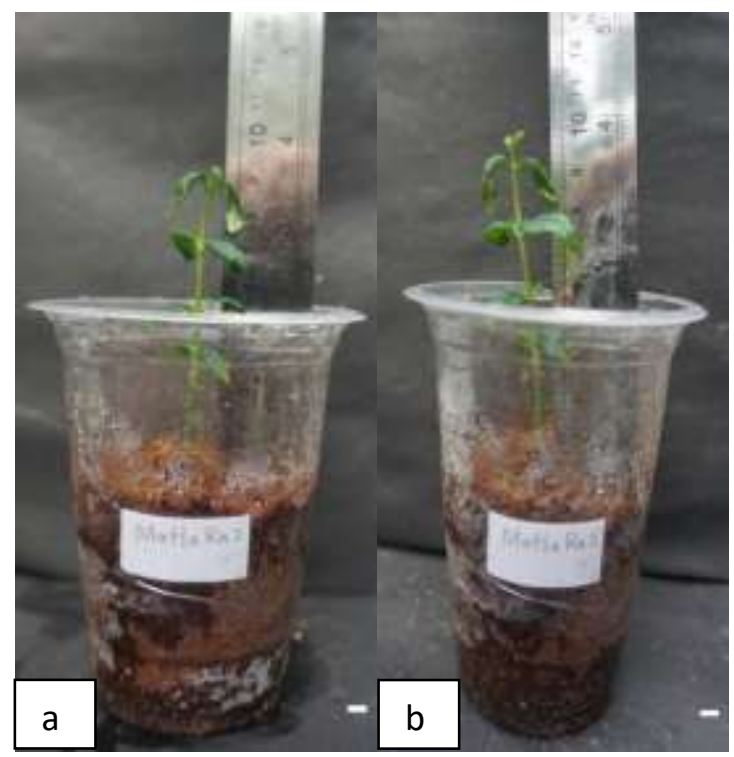

Gambar 3. (a dan b) Penambahan tinggi tanaman. Scale bar: $2 \mathrm{~cm}$

Hasil analisis Anava tiga arah adalah sumber hormon alami berpengaruh signifikan terhadap tinggi tanaman. Hasil uji lanjut sumber hormon alami menunjukkan bahwa ekstrak tauge memiliki pengaruh yang setara dengan IBA (Tabel 6).

Tabel 6. Hasil uji Duncan pada hormon terhadap tinggi tanaman planlet pule pandak

\begin{tabular}{cc}
\hline Hormon & Tinggi tanaman \\
\hline IBA & $7,54^{\mathrm{a}}$ \\
Air kelapa & $6,11^{\mathrm{b}}$ \\
Ekstrak tauge & $7,81^{\mathrm{a}}$ \\
\hline
\end{tabular}

Ekstrak tauge dapat dijadikan sebagai alternatif pengganti hormon IBA dalam aklimatisasi. Adanya kandungan hormon auksin dan giberelin dalam ekstrak tauge mempengaruhi tinggi tanaman. Hal ini dikarenakan giberelin dapat meningkatkan pembelahan dan pertumbuhan sel yang menyebabkan terjadinya pemanjangan batang. Hormon auksin juga dapat mempengaruhi pemanjangan sel akan tetapi lebih efektif jika diberi pada potongan-potongan organ tanaman, hormon giberelin lebih efektif digunakan pada tanaman yang utuh (Asra et al. 2020). Mekanisme kerja hormon 
giberelin dalam pemanjangan sel berkaitan dengan kemampuan dalam pengembangan dinding sel. Giberelin mendorong terbentuknya enzim amilase sehingga terjadi hidrolisa pati yang mengakibatkan terjadinya peningkatan konsentrasi gula yang menyebabkan tekanan osmotik sel meningkat. Ujungujung sel akan cenderung berkembang (Patma et al. 2013).

\section{Persentase Hidup}

Hasil penelitian menunjukkan bahwa jenis media, sumber hormon alami dan teknik induksi akar planlet tidak berpengaruh terhadap persentase planlet hidup dari awal sampai pada $4 \mathrm{MST}$. Hal ini ditunjukkan dengan planlet hidup 100\%. Tingginya keberhasilan hidup planlet pule pandak karena media yang digunakan bebas dari patogen dan faktor lingkungan yang terkontrol.

Media yang disterilisasi menggunakan autoklaf sebelumnya telah terbukti bebas dari patogen yang dapat menyebabkan kematian pada planlet. Cahyani (2009) menyatakan teknik sterilisasi media menggunakan autoklaf dapat mematikan bakteri dan jamur. Selain itu, perlakuan sterilisasi media berpengaruh nyata terhadap pertumbuhan tanaman. Teknik sterilisasi media menggunakan autoklaf dengan suhu $121^{\circ} \mathrm{C}$ selama 20 menit dapat meningkatkan pertumbuhan tanaman.

Faktor lingkungan yang mempengaruhi persentase planlet hidup adalah suhu, intensitas cahaya dan kelembaban. Suhu yang dikontrol pada penelitian ini berkisar $27^{\circ} \mathrm{C}$. Suhu tersebut optimal untuk pertumbuhan pule pandak yang di aklimatisasi. Pujiyanto (2006) menyatakan suhu memiliki peran dalam pertumbuhan tanaman karena berhubungan dengan aktivitas enzim.Enzim adalah senyawa yang berperan sebagai katalisator dalam metabolisme tanaman.Enzim dapat bekerja pada kondisi suhu optimal. Enzim dapat mengalami denaturasi jika suhu terlalu tinggi dan jika suhu terlalu rendah enzim akan mengalami inactive. Pada penelitian seluruh planlet yang ditanam dapat tumbuh dengan baik sehingga pada suhu yang dikontrol tidak mempengaruhi kerja enzim.

\section{SIMPULAN}

Hasil penelitian menunjukkan bahwa jenis media tidak berpengaruh terhadap persentase hidup dan pertumbuhan planlet pule pandak. Sumber hormon alami tidak berpengaruh terhadap persentase hidup tetapi berpengaruh terhadap pertumbuhan planlet pule pandak. Sumber hormon alami terbaik untuk aklimatisasi pule pandak adalah ekstrak tauge yang hasil uji statistiknya setara dengan hormon sintetik IBA $1 \mu \mathrm{M}$. Teknik induksi akar tidak berpengaruh terhadap persentase hidup planlet tetapi berpengaruh terhadap pertumbuhan planlet. Teknik induksi akar yang paling baik adalah teknik induksi akar secara in vitro.

\section{UCAPAN TERIMA KASIH}

Saya ucapkan terima kasih kepada Prof. Dr. Enni Suwarsi Rahayu, M.Si. selaku dosen pembimbing yang selalu memberikan masukan dan pengarahan selama pembimbingan skripsi. 


\section{DAFTAR PUSTAKA}

Arif, M., Murniati, \& Ardian. (2016). Uji Beberapa Zat Pengatur Tumbuh Alami Terhadap Pertumbuhan Bibit Karet (Hevea brasiliensis Muell Arg) Stum Mata Tidur. Jurnal Ilmu Pertanian, $3(1)$.

Artanti, F. Y. (2007). Pengaruh Macam Pupuk Organik Cair dan Konsentrasi IAA Terhadap Pertumbuhan Setek Tanaman Stevia (Stevia rebaudiana Bertoni M.). Skripsi Universitas Sebelas Maret.

Artha, T. (2014). Interaksi Pertumbuhan antara Shorea selanica dan Gnetum gnemon dalam Media Tanam dengan Konsentrasi Cocopeat yang Berbeda. Skripsi Institut Pertanian Bogor.

Asra, R. (2020). Pengaruh Hormon Giberelin (GA3) terhadap Daya Kecambah dan Vigoritas Calpogonium caeruleum. Jurnal Biospecies, 7(1), 29-33.

Cahyani, V. R. (2009). Pengaruh Beberapa Metode Sterilisasi Tanah Terhadap Status Hara, Populasi Mikrobiota, Potendi Infeksi Mikorisa dan Pertumbuhan Tanaman. Jurnal Ilmiah Ilmu Tanah dan Agroklimatologi, 6(1), 43-52

Fadhillah, L. (2015). Pengaruh Pemberian Ekstrak Tauge pada Media MS Modifikasi terhadap Pertumbuhan Planlet Kentang Granola (Solanum tuberosum L. cv Granola) Secara In Vitro. Skripsi Universitas Syiah Kuala.

George, E. F., Hall, M. A., de Klerk, G. J. (2007). Plant propagation by tissue culture. The Netherlands.

Jayanti, F. D., Duryat \& Bintoro, A. (2019). Pengaruh Ekstrak Tauge dan Bawang Merah pada Pertumbuhan Bibit Gaharu (Aquilaria malaccensis). Jurnal Belantara, 2(1), 70-75.

Khan, S., Banu, T. A., Akter, S., Goswani, B., Islam, M., Hani, U., Habib, A. (2018). In Vitro Regeneration Protocol of Rauvolfia serpentina L. Bangladesh Journal of Scientific and Industrial Research, 53(2), 133-138

Kristina N. N. \& Syahid, F. S. (2012). Multiplikasi Tunas, Aklimatisasi dan Analisis Mutu Simplisia Daun Encok (Plumbago zeylanica L.) Asal Kultur In Vitro Periode Panjang. Bul. Littro, 212(2), 117-128.

Kusumawati, K., Muhartini, S., Rogomulyo, R. (2015). Pengaruh Konsentrasi dan Frekuensi Pemberian Limbah Tahu Terhadap Pertumbuhan dan Hasil Bayam (Amaranthus tricolor L.) pada Media Pasir Pantai. Vegetalika, 4(2), 48-62.

Maligan, J. M. (2014). Food Chemistry Protein Analysis. Surabaya: FTB-UB.

Mariska, I. \& Sukmadjaja, D. (2003). Perbanyakan Bibit Abaka melalui Kultur Jaringan. Bogor: Balai Penelitian Bioteknologi dan Sumberdaya Genetik Pertanian.

Mukherjee, E. S., Sarkar. Bhattacharyya, S., Gantait, S. (2020). Ameliorated Reserpine Production Via In Vitro Direct and Indirect Regeneration System in Rauvolfia serpentina (L.) Benth. ex Kurz. 3 Biotech, 10(294), 1-14.

Patma, U., Lollie, A. P. P., Luthfi, A. M. S. (2013). Respon Media Tanam dan Pemberian Auksin Asam Asetat pada Pembibitan Aren (Arenga pinnata Merr.). Jurnal Online Agroekoteknologi, 1(2), 286-295.

Prasetyawan, D. (2009). Sifat Fisis dan Mekanis Papan Komposit dari Serbuk Sabut Kelapa (Cocopeat) dengan Plastik Polyethylene.Skripsi Institut Pertanian Bogor.

Priyadi, A. \& Hendriyani, E. (2016). Karakter Morfo-Fisiologi Daun Tiga Jenis Planlet Anggrek pada Tahap Aklimatisasi. J. Hort, 26(2), 143-152.

Pujiyanto. (2006). Menjelajah Dunia Biologi. Jakarta: PT Tiga Serangkai Pustaka Mandiri.

Purmadewi, G. C., Wulandari, A. S., Damayanti, R. U. (2019). Pengaruh Metode Pengakaran dan Media Aklimatisasi terhadap Keberhasilan Aklimatisasi Tembesu (Fagraea fragrans (Roxb.)Miq). Jurnal Perbenihan Tanaman Hutan, 17(1), 1-12.

Sandra, E. (2013). Cara Mudah Memahami dan Mengenal Kultur Jaringan. Bogor: IPB Press.

Slamet. (2011). Perkembangan Teknik Aklimatisasi Tanaman Kedelai Hasil Regenerasi Kultur In Vitro. Jurnal Litbang Pertanian, 30(2), 48-54.

Sunandar, Anggraeni, N., Faizin, A. N. A., Ikhwan, A. (2017). Kuantifikasi Metabolit Sekunder pada Ekstrak Kecambah Kacang Hijau, Kacang Tunggak, dan Kacang Tanah dengan Teknik GC-MS. Prosiding Seminar Hasil Penelitian Tanaman Aneka Kacang dan Umbi. 
Ulfa, F. (2014). Peran Senyawa Bioaktif Tanaman Sebagai Zat Pengatur Tumbuh dalam Memacu Produksi Umbi Mini Kentang Solanum tuberosum L. pada Sistem Budidaya Aeroponik. Disertasi Universitas Hasanuddin.

Widaryanto, E. \& Azizah, N. (2018). Perspektif Tanaman Obat Berkhasiat. Malang: UB Press. 